\title{
KVANTITATÍV TÁRSADALMI TÉRELEMZÉSI ESZKÖZÖK A MAI REGIONÁLIS TUDOMÁNYBAN ${ }^{1}$
}

\author{
(Elements of Quantitative Spatial Analysis \\ in the Recent Regional Science)
}

\author{
NEMES NAGY JÓZSEF
}

Kulcsszavak:

regionális tudomány kvantitatív elemzés térparaméterek terïleti autokorrelácio- és autoregresszió

Bár a regionális tudomány félévszázados fejlödése során mind tematikajában, mind módszertanában átalakult, kibövült, kutatási alapkérdése továbbra is a tér és a társadalom viszonya, elemzési eszközei közört pedig kiemelt fontosságúak a kvantitatív módszerek. A kvantitatív elemzés fö témái közé tartozik a területi egyentôtlenségek vizsgálata. A térbeli tagoltság hatótényezöi között a têr $r$ a földrajzi adottságok súlyának, szerepének megvilágítása, mérése is többfajta kvantitatív módszert kíván. A térbeli egymásrahatások, a térbeli közelség következtében megjelenö autokorreláltság vizsgálata a modern területi elemzések leginkább elötérben álló új nódszertani eleme.

\section{Bevezetés}

A Walter Isard által 1954-ben a Pennsylvaniai Egyetemen, a máig vitatott névadással létrehozott, majd széleskörüen intézményesülö regional science (regionális tudomány) indulásakor - nagyívü szintetizáló tudományos programja dacára - dominánsan közgazdasági bázisú, módszertani szemléletében pedig kvantitatív elemzỏ és modellezö kutatási irányzatként volt azonosítható (lásd: Isard 1956; 1960; Boyce 2004).

Jól érzékelhetô ellenben, hogy a tudománytörténeti áttekintések (pl. Benko 1999; Polèse 1999) milyen nagy hangsúllyal keresik és mutatják ki - utólagosan - a regionális tudomány diszciplinárisan szerteágazó gyökereit és hatóterét, amelyek a közgazdaságtanon túl leginkább a földrajz (Haggett 2006), a szociológia (Farkas 2003a; 2003 b; Bangó 2006), az urbanisztika (Meggyesi 2002) felé nyúlnak.

$\mathrm{Az}$ induláskor még meghatározó kvantitatív modellező szemlélet sem átfogó jellegmeghatározó tudományos jegye ma már a regionális kutatásoknak, hanem csak egyik elemének minősül a tudományterület módszertani eszköztárának²

Magam, bár kifejezetten nem történeti közelítésben, nem a gyökereket, hanem a megoldandó tudományos feladatokat keresve, ugyancsak egy szélesebb diszciplináris kérdéskör vizsgálatában használható (,társadalmi tértudományi”) szemlélet fontosságának felismeréséig jutottam el (Nemes Nagy 1998). Eltávolodva az isardi közgazdasági kiindulóponttól a területi fejlettségi különbségekre koncentráló empirikus kutatásaimban a gazdasági folyamatokhoz való kötódésem azonban fennmaradt, s ebben az értelemben regionalistának vallom magam s nem térkutatónak ${ }^{3}$. A módszertani momentumban ugyanakkor a konzervatív vonalat képviselem, s azt - idehaza - életben tartani igyekszem ${ }^{4}$ a magam kutatásaival és oktatómunkámban: a regionális tudománynak a 
Nemes Nagy József : Kvantitatív társadalmi térelemzési eszközök a mai regionális tudományban. Tér és Társadalom 21. évf. 2007/1. 1-19. p.

biztos társadalmi térelméleti alapok mellett esszenciális elemének ítélve a kvantitatív, modellezô közelítést. Ezt nem nélkülözheti semmilyen posztmodern fïlozófiai bázisú térszemlélet és területpolitika sem (melyek maguk is mérni kényszeriilnek, ha néha röstellik is az ilyesfajta durva közelítést).

Tanulmányomban - a mondandó megértését elősegítő általánosabb jegyek, fejlődéstendenciák rövid áttekintése után - a kvantitatív eszköztárnak a legújabb idöszak nemzetközi területi elemzö szakirodalmából kiolvasható néhány „régi-új és új-új” elemzési problémakörére és eszközére összpontosítok. Ezek egy részét a magyar kutatók is jól értik, használják, mások esetében azonban még előttünk áll a konkrét kutatómunkában való kipróbálás gyötrelmes-örömteli munkája. Áttekintésem erre bíztat!

\section{Társadalom és tér, tér és társadalom}

Mindenfajta változás, tematikai bővülés és a módszertani sokszínüség ellenére a regionális tudományi munkáknak mindvégig megmaradt a tér és a társadalom viszonyát, a társadalmi térbeliséget firtató alapkaraktere.

A gyakoribb kiindulópontot e két nagyon általános és átfogó kategória közül egyértelmúen a társadalom, a társadalmi problémák jelentik, amelyekhez a térbeliség szerepének megvilágítása utólag párosul. A közgazdaságtanban például a klasszikus modellek sokat emlegetett ,egypont"-szemlélete ugyan még ma sem tünt el teljesen, de ma már legalább ilyen gyakran emlegetett modell az „új gazdaságföldrajzé” (Krugman 1998). Ez azt, a földrajzosok által hosszú időn át - mondhatni a geográfia kezdeteitöl fogva - szélesebb tudományos figyelmet alig keltően, de egyértelmüen képviselt szemléletet, amit a földrajzi adottságoknak a fejlődésre gyakorolt hatása jelent, fedezi újra fel (s fordítja a közgazdaságtan nyelvére), felismerve, hogy a fejlödés-elmaradás duál a térben nem véletlenszerüen, hanem meghatározott térbeli konfigurációban (centrum-periféria relációkban) van jelen. Ez a felismerés ma azonban már jóval atfogóbb formában is jelen van a társadalomkutatásban: sok vizsgálat, a legkülönbözőbb térségi szinteken és aggregációkban, színes társadalmi tartalommal ugyanis egyértelmúen igazolja ugyanezt akkor, amikor a társadalmi jelenségek térbeli autokorreláltságára (a szomszédsági hasonulásra) hívja fel a figyelmet. Ez egyúttal egy szinte forradalmi erejü módszertani fordulatnak is az alapja (lásd később).

Ha a kutató a társadalom és a tér viszonyát a tér oldaláról indulva közelíti (ez ritkább), két jellegzetes, sokat vitatott, akár tévútnak is minösíthetö szemlélet és eszköztár is felbukkan. Az elsőt a nyelvében ,túlmatemetizált" modellszemlélet elméleti konstrukciói, a másodikat pedig a hagyományos geográfia „minden hely egyedi”szemlélete, az ehhez virulensen kötödő földrajzi determinizmus képviseli. Mindkét közelítés egyoldalúsága azzal is összefügg, hogy a „térbeli” (földrajzi) és a ,nemtérbeli" (társadalmi, strukturális) tényezők kombinált hatásmechanizmusát elméletileg is nehéz feltárni, módszertanilag pedig még sokszor kimunkálatlan az együttes elemzés. Mindezek dacára nincs más lehetőség, mint az elválasztás és az együttkezelés nehéz, dialektikus útja. 
Nemes Nagy József : Kvantitatív társadalmi térelemzési eszközök a mai regionális tudományban.

Tér és Társadalom 21. évf. 2007/1. 1-19. p.

TÉT XXI. évf. 2007 匹

Kvantitatív társadalmi térelemzési ...

A mai regionális kutatásokra tekintve egyaránt találunk ezeket nehezítő tényezőket és új esélyeket, felértékelő mechanizmusokat.

Ha sorra vesszük a társadalmi térbeliség, a területiség tudományos vizsgálatát nehezítö körülményeket, akkor a következő momentumok említhetők:

- Az elméleti és a deduktív közelítés gyönge hagyományai a területi kutatásokban (tisztázatlan, többértelmú térkategóriák), elméletmentes, gyakorlatias közelítések

- Az igényes térelemzés munkaigényessége, fáradságos volta (kibúvó: „fapados”, elemzésmentes, deklaratív publikációk)

- Módszertani nehézségek (pl. analógia-korlátok a társadalmi jelenségek vizsgálatára alkalmazott természeti, fizikai modellek használatakor vagy a térkutatás legalapvetöbb statisztikai korlátja, az ún. „módosítható területi egység" probléma)

- Mivel az általános (társadalmi) körülmények és szabályozás közvetett területi hatásai gyakran jóval erősebbek, mint a speciális térbeli feltételeké és a célzottan területi szabályozásé (lásd a piaci tökemozgások, illetve a területfejlesztési eszközök hatásai közötti nagyságrendi különbséget a piacgazdaságokban az előzőek javára), így a térfaktorok beemelése a vizsgálatokba néha eröltetettnek tünik.

E fékekkel szemben a legújabb időszakban azonban több olyan tényezö is felerösödőben van, ami kifejezetten serkenti, ösztönzi a területi kutatásokat, ugyanakkor újra elötérbe hozza a kvantitatív közelítést is.

Elsőként a területi dimenzió iránt megnyilvánuló, egyre határozottabb társadalmi, politikai érdeklödés említendö. E mögött lényegében egyetlen alapvető tény bújik meg: a térbeli (fejlettségi) tagoltság, polarizáció magas szintje világméretekben, az országok jó részében, a regionális és települési terekben. Ehhez még hozzá jön az, hogy a huszadik század második felét a fejlett országokban egyértelmúen uraló területi közeledési, nivellálódási trend a századvégen (lényegében már 1980 után) megtört, a szegénység, a területi leszakadás újra gond ott is, valamint az is, hogy a rendszerváltó, illetve a felzárkózó, újonnan iparosodó országok mindegyikében szélsőséges és növekvö belsö területi differenciáltság mellett zajlik az átalakulás.

Miközben ezek a folyamatok a feszültségek oldaláról helyezik a figyelem középpontjába a regionalitåst (fó elemeként a fekvési elönyökkel és hátrányokkal), társadalompolitikai szempontból egyre elfogadottabb az, hogy e feszültségeket a társadalomirányítás decentralizálásának, regionalizálásának növelésével enyhíteni lehet. Mindez növekvő igényt, „piacot” terem a területi kutatásoknak (igaz esetenként alacsony igényszintü piacot).

A térbeliség felértékelödésén túlmenően, kifejezetten a kvantitatív eszköztár újjáéledését serkenti két új elem: a területi adatnyerési lehetóségeket is megsokszorozó információs-boom és a térelemzés új eszköze, a GIS, a földrajzi információs rendszerek számítástechnikai eszköztára ${ }^{5}$. A nagyságrendjében megnövekedett, nyilvános területi statisztikai információk soha nem látott lehetöségeket nyitnak a területi kutatások elött minden területi szinten. Ma tulajdonképpen az információk bỏsége a gond. 


\section{A tagolt világ}

A térbeliség két alapkomponense, az egyenlötlenség (területi differenciáltság) és a rendezettség (konfiguráció) közül a mennyiségi elemzéseket használó területi kutatásokat hosszú ideig az első komponens uralta, a rendezettség illusztratív szinten, mélyebb elemzés nélkül megrekedt a térképek készítésénél. (Az egyenlötlenség és konfiguráció duálja sok tekintetben analóg a régió és a térszerkezet fogalmi kettősségével [Szabó 2006].)

Az egyenlötlenségkutatás alapkérdése: mekkorák, hogyan változnak a terïleti egyenlötlenségek? Ebben a közelítésben - bármilyen térségi szinten, bármilyen témakörben ${ }^{6}$ folyik is a vizsgálódás - a nagyobb egységek dezaggregálásával vizsgáljuk az adott jelenség belső, területi tagolódását (ez jellegzetes területi statisztikai közelítés).

A korábbiakban említett információs robbanás talán ebben a kérdéskörben a leglátványosabb. Szinte nincs olyan darabja a Földnek, amelyröl ne rendelkeznénk mért vagy számbavett természeti (környezeti) vagy társadalmi információkkal. A nemzeti adatközléseken túl a nemzetközi kooperáció eredményeként, a nagy világszervezetek háttérmúhelyeiben folyó munka egyre több, azonos módszerekkel számbevett, egymással kompatibilis információt eredményez és hoz nyilvánosságra (a legismertebb ezek közül az EUROSTAT egységesített REGIO-adatbázisa, tágabb országkörre kitekintő elemzést adott közre nemrég a többségében fejlett országokat tömörítö $\mathrm{OECD}$ a tagországok regionális tagoltságát azonosan metódusokkal tárgyaló kötetében - OECD 2005).

$\mathrm{Az}$ adatbőségnek bizonyos tekintetben paradox kíséröjelensége ugyanakkor az, hogy - noha erre az információk ma már meglennének - a térségi fejlettségvizsgálatokban világszerte érzékelhetöen visszaszorult a leginkább a hetvenes-nyolcvanas évekre jellemzö többváltozós matematikai-statisztikai közelítés (ennek fö eszköze a faktoranalizis volt), a területi tagozódás, osztályozás jellemzően egy-egy kiemelt mutatószámra szükül (regionális fejlettség: GDP/fö, vidékiség-ruralitás: népsürüség, de nem sokkal bonyolultabb a sokat emlegetett HDI sem). Mindez jórészt azzal függ össze, hogy ma ezek a kutatások nem elsődlegesen tudományos célúak (amennyiben azok, akkor megmarad az összetettebb eszköztár), hanem a támogatáspolitikák kiszolgálására készülnek. Itt pedig kiemelt szempont a szélesebb társadalmi kontrollt lehetővé tevő viszonylagos közérthetöség, ami csak így biztosítható (a polgármesterektôl nem várható el a faktoranalízis értő ismerete).

A kutatások leggyakoribb térségi szintjét az országok alkotják, de folyamatos a kutatói törekvés a finnomabb bontású információk használatára. Ebben két jellegzetes kỏzelítés érdemel említést. Az egyik a nemzeti (háztartási, személyi) jövedelemfelvételek felhasználásával finomítja az országos átlagokra épülő elemzést, eltávolodva a „területi” számbavételtỏl (lásd pl. Milanovic 2002, aki a Világbank vezetó elemzójeként számos tanulmányt publikált a világméretủ egyenlötlenségek témakörében). 
Nemes Nagy József : Kvantitatív társadalmi térelemzési eszközök a mai regionális tudományban.

Tér és Társadalom 21. évf. 2007/1. 1-19. p.

TÉT XXI. évf. 2007 - 1

Kvantitatív társadalmi térelemzési ... 5

De találkozhatunk olyan kutatásokkal is, ahol a kifejezett cél a finomabb területi számbavétel, a kistérségi becslés, amelyek jellemző közelítésként „négyzethálóval" kijelölt, azonos területű elemi egységeket töltenek fel információval. Európai példaként említést érdemelnek az INRETS kutatóintézetnek a Raster-Net adatbázisra épülö gridtérképei (www.inrets.fr), míg a világméretủ fejlettségi, jövedelmi térképekről lásd a Yale egyetemen W. Nordhaus által vezetett kutatás eredményeit (http://gecon.yale.edu/). Az e kutatásokban használt azonos térméretü alapegységek, kétségkívül járnak módszertani, összehasonlíthatósági haszonnal, de valóságos társadalmi tartamát tekintve határozottan kiüresítik a társadalmi teret. Aligha rendelhetö ugyanis ezen semleges alapegységekhez bármifajta valóságos térszerveződés, nem beszélve a térfolyamatokat mozgató társadalmi kötődés, identitás vagy irányítás momentumairól. Utóbbiak jellemzően a nehezen összehasonlítható, de „nevesített”, valóságos térszervezési funkciókhoz kötő téregységekhez (a szubnacionális szintek különböző egységeihez, régióihoz) kötődnek. Magam vizsgálataimban ezeknél maradtam, még ha nagy csodálója vagyok is a fentiekben említett dezaggregált adatháttérrel készuilt látványos térképeknek (ezek is megtalálhatók a citált forráshelyeken).

E kibővült információbázisból, ha nem is automatikusan (becsléseket, korrekciókat alkalmazva) kiolvasható összefüggések példájaként hozom ide az l. táblázatot. Az elmúlt években elvégzett adatgyủjtéseim eredményeként a világ 228 országa közül 112-nek összesen több mint 6400 szubnacionális területegységére sikerült összegyüjtenem (részben becsülnöm) adatokat a népesség és a jövedelmek nagyságáról, s ezek felhasználásával a gazdasági fejlettség területi tagoltságáról (Nemes Nagy 2006). Ezek az adatok részletesebb elemzés nélkül is érzékeltetik a sokat emlegetett világméretü fejlettségi szakadék mélységét valamint az egyes makrorégiók belső tagoltságának a különbségeit is? .

A statikus, egy időpontra vonatkozó keresztmetszeti elemzések mellett ugyanebbe a vizsgálati körbe tartozik a területi egyenlötlenségek alakulásának kérdésköre is. Vajon nönek (divergencia) vagy csökkennek (konvergencia) a területi egyenlötlenségek? Ez ma is elsörendü kutatási (vita)kérdés minden térségi szinten.

A világméretü jövedelemegyenlötlenségek alakulása kapcsán egyre többször merül fel az, hogy bizonyos jelei vannak a fejlettségi olló szükülésének (Major 2001; Sala-i-Martin 2002; Heshmati 2006). E mögött egy nagyon határozott földrajzi lokalizáltságú jelenség áll, Kelet- és Dél-Ázsia feltörekvő hatalmainak (Kína s újabban India) látványos fejlödése. A világos, végleges választ - a ,fejlődés, fejlettség" elvi vitathatóságán túlmenően - kétség kívül bonyolítja, hogy az országos szintü fejlödés sok helyütt éles belsö regionális polarizáltsággal párosul. Más kérdés az, hogy a folyamatra nagytávlatban tekintve a mai világméretủ polarizáltságot épp az különbözteti meg az egy évszázaddal előbbitől, hogy az országok közötti fejlettségi különbségek sokszorozódtak meg, míg a belső egyenlőtlenségekre ugyanezen időtávú összevetésben inkább a relatív konvergencia vagy a stagnálás a jellemző. A világméretü egyenlőtlenségek jövőbeni alakulásának az említett felzárkozó nagyhatalmak mellett kulcsszereplöje Fekete-Afrika. Amennyiben ott nem indul meg a gyorsabb fejlödés, egy szűkebb földrajzi kiterjedésủ negatív pólussal ugyan, de végletes polarizáltság jelezhető előre, alig belátható feszültségekkel. 
Nemes Nagy József : Kvantitatív társadalmi térelemzési eszközök a mai regionális tudományban.

Tér és Társadalom 21. évf. 2007/1. 1-19. p.

$6 \quad$ Nemes Nagy József

TÉT XXI. évf. 2007

\section{TÁBLÁZAT}

A világ egyes makrorégiói legfejlettebb és legelmaradottabb területegységei és a fejlettségi olló (becsült GDP/fö, 2002, PPS\$)

(Regional Polarisation of Development Level in the Macroregions of the World)

\begin{tabular}{|c|c|c|c|c|c|}
\hline Makrorégiók & $\begin{array}{c}\text { Legfejlettebb } \\
\text { térség }\end{array}$ & $G D P / f o$ & $\begin{array}{c}\text { Legfejletlenebb } \\
\text { térség }\end{array}$ & $G D P / f o ̈$ & MAX/MIN \\
\hline Afrika & Cabinda (AN) & 64100 & Kisumu $(K E N)$ & 100 & $641: 1$ \\
\hline Mediterrán Afrika & $\begin{array}{l}\text { Nagy-Tunisz } \\
\text { (TUN) }\end{array}$ & 9000 & Assyout (EG) & 2200 & $4: 1$ \\
\hline $\begin{array}{l}\text { Szub-szaharai } \\
\text { Afrika }\end{array}$ & Cabinda (AN) & 64100 & Kisumu (KEN) & 100 & $641: 1$ \\
\hline Amerika & $\begin{array}{l}\text { Washington D. C. } \\
\text { (USA) }\end{array}$ & 116900 & $\begin{array}{l}\text { Ngöbe Buglé (PAN), } \\
\text { Arque (BOL) }\end{array}$ & 400 & $292: 1$ \\
\hline Észak-Amerika & $\begin{array}{l}\text { Washington D. C. } \\
\text { (USA) }\end{array}$ & 116900 & $\begin{array}{l}\text { Sant Pierre és } \\
\text { Miquelon }\end{array}$ & 11000 & 11:1 \\
\hline Közép-Amerika & $\begin{array}{l}\text { Mexikóváros } \\
\text { (MEX) }\end{array}$ & 22300 & Ngöbe Buglé (PAN) & 400 & $56: 1$ \\
\hline Karib sz. & $\begin{array}{l}\text { KAJMÁN SZ. } \\
\text { (UK) }\end{array}$ & 35000 & HAITI & 1400 & $25: 1$ \\
\hline Dél-Amerika & $\begin{array}{l}\text { Norte Fluminense } \\
\text { (BR) }\end{array}$ & 46000 & Arque (BOL) & 400 & $115: 1$ \\
\hline Ázsia & Osaka v. (JAP) & 63800 & Baucau (K-TIMOR) & 300 & $213: 1$ \\
\hline $\begin{array}{l}\text { Dél- és Kelet } \\
\text { Ázsia }\end{array}$ & Osaka v. (JAP) & 63800 & Baucau (K-TIMOR) & 300 & 213:1 \\
\hline Ny-Ázsiai & Abu Dhabi (EAE) & 32600 & Abyan (JEM) & 500 & $65: 1$ \\
\hline $\begin{array}{l}\text { Ausztrália- } \\
\text { Óceánia }\end{array}$ & $\begin{array}{l}\text { Darwin és kör- } \\
\text { nyéke (AUS) }\end{array}$ & 41000 & Kiribati & 800 & $41: 1$ \\
\hline $\begin{array}{l}\text { Ausztrália-Új- } \\
\text { Zéland }\end{array}$ & $\begin{array}{l}\text { Darwin és kör- } \\
\text { nyéke. (AUS) }\end{array}$ & 41000 & Wiluna (AUS) & 3600 & $11: 1$ \\
\hline Óceánia & GUAM (USA) & 21000 & Kiribati & 800 & $26: 1$ \\
\hline Európa & $\begin{array}{l}\text { Inner-London- } \\
\text { West }(U K)\end{array}$ & 123300 & Hegyvidéki r. (ALB) & 400 & $308: 1$ \\
\hline $\begin{array}{l}\text { Nem EU-tag DK- } \\
\text { Európa }\end{array}$ & Kocaeli (TUR) & 21000 & Hegyvidéki r. (ALB) & 400 & $53: 1$ \\
\hline $\begin{array}{l}\text { Nem EU-tag } \\
\text { Nyugat-Európa }\end{array}$ & Oslo (NOR) & 52000 & Gibraltár (UK) & 17500 & $3: 1$ \\
\hline $\begin{array}{l}\text { Uj EU-tagok } \\
\text { (EU10) }\end{array}$ & Prága (CSEH) & 34600 & Rêzekne (LETT) & 2300 & $15: 1$ \\
\hline $\begin{array}{l}\text { Régi EU-tagok } \\
\text { (EU15) }\end{array}$ & $\begin{array}{l}\text { Inner-London- } \\
\text { West (UK) }\end{array}$ & 123300 & Tâmega (POR) & 9700 & $13: 1$ \\
\hline Volt SZU & $\begin{array}{l}\text { Hanti-Mansi a. o. } \\
\text { (RUS) }\end{array}$ & 64800 & $\begin{array}{l}\text { Kalbahar-Lachin } \\
\text { (AZE) }\end{array}$ & 300 & $216: 1$ \\
\hline Világ & $\begin{array}{l}\text { Inner-London- } \\
\text { West (UK) }\end{array}$ & 123300 & Kisumu $(K E N)$ & 100 & $1233: 1$ \\
\hline
\end{tabular}

Forrás: Nemes Nagy J. 2006, 207. o.

A témához láthatóan kedvet kapott közgazdász szakmai kör a vizsgálati eszközök közül a korábbiakban uralkodó, strukturalista indíttatású $\sigma$ (szigma)-konvergencia közelítéssel (a területi jövedelemszóródás alakulása) szemben sokkal inkább a növekedéselméleti alapú ún. $\beta($ béta)-konvergencia (a fejlettségi szint és a növekedési ütem közötti kapcsolat) tesztelését preferálja (az első munkák közül gyakran citált 
Nemes Nagy József : Kvantitatív társadalmi térelemzési eszközök a mai regionális tudományban. Tér és Társadalom 21. évf. 2007/1. 1-19. p.

Barro 1988, újabb, átfogóbb értékelését adja a módszernek lásd Abreau et al. 2005b). Az első szemléletben az egyenlötlenségek csökkenéséről (konvergenciáról) a jövedelemszórás (vagy más egyenlötlenségi index) csökkenésekor beszélünk, a második esetben a közeledés, a konvergencia akkor következik be, ha a fejlettségi szint és a növekedési ütem között negatív korrelációs (regressziós) kapcsolat mutatkozik, ha a szegények gyorsabban, a gazdagok lassabban gyarapodnak.

A kétfajta közelítés felbukkanásával azonnal egy újabb módszertani vitapont is megteremtődik, mivel a kétfajta szemlélet nem feleltethetỏ meg közvetlenül egymásnak. Matematikai meghatározást használva: a szigma konvergenciának (a szóráscsökkenésnek) szükséges, de nem elégséges feltétele a béta-konvergencia. Tipikusan ez a helyzet akkor, amikor egy országban - általában hosszabb időtávon - „fejlettségi inverziơ” játszódik le, ami akkor következhet be, ha a kezdetben elmaradottabb térségek gyorsabban, a fejlettebbek lassan fejlődnek. Ez a folyamat a béta-konvergencia logikájában kezdetben kiegyenlitỏdést hoz, ha azonban olyannyira ,túlfut”, hogy a két régió helyet cserél egy mással a fejlettségi skálán, ekkor elóállhat az a helyzet, hogy a szórás viszszaáll az eredeti szintre (azaz nincs szigma-konvergencia). E relációra klasszikus példa Flandria és Vallonia fejlettségi helycseréje az elmúlt ötven évben Belgiumon belül.

Mindkét konvergencia-szemléletnek megvannak a korlátai. Közös korlát a térfelosztástól, a vizsgálati szinttool való függés és a vizsgálati időtáv kiválasztása. A szigmakonvergencia kutatásokban egyértelmü összefüggés az, hogy a dezaggregáltabb rendszerekben általában nagyobb differenciáltsági mértékek adódnak, mint az összevontabbakban, a béta-konvergencia közelítésekben az feltételezhetö, hogy a dezaggregált rendszerekben kevésbé markáns a kiegyenlítődési (utolérési) tendencia. A szigmakonvergencia kutatásokban a sokfajta egyenlootlenségi index használata okoz értelmezési, összehasonlítási gondokat az eredmények értékelésekor. A béta-konvergencia egységes (regresszio-számítási alapú) logikájában a fentiekben említett általánosabb korlátokon túlmenően a legvitatottabb momentum a közelítés elméleti bázisát alkotó Solow-modell egyszerú, de nagyon szigorú feltételrendszere (tisztán piaci mechanizmusokon nyugvó, „külső” beavatkozásokat kizáró fejlődés), ez a valóságban ugyanis sohasem teljesül. A finomított modell (az ún. feltételes konvergencia) az alapmodellt kiegészítve azt állítja, hogy a konvergencia (a szegény, elmaradott térségek feltételezhető felzárkózása) csak akkor igazolható elméletileg is, ha a gazdasági növekedés általánosabb (társadalmi) feltételei területi eltéréseinek hatását kiszürjük. Ez empirikusan egy olyan regresszió modellt javall, amiben nem pusztán a fejlettségi szint és a növekedési ütem kerül összekapcsolásra, hanem a magyarázó változók közé más indikátorok (pl. infrastrukturális jellemzők, a humán kapacitás, iskolázottság, a technológiai színvonal vagy akár a területi hatalmi pozíciók, hatáskörök különbözöségeinek mutatói) is bekerülnek. Minden aztán nagyon széles indikátor-szortimentet eredményez, s az összemérhetöséget csupán az egyértelmú trendek esetében alapozza meg.

A vizsgálatok érdekes sajátosságaként újabban a differenciáltság, egyenlőtlenség fogalma és mérése helyébe több tanulmányban a polarizáltság kategóriája kerül (Ezkurra et al. 2005), leképezve azt a jelenséget, hogy világméretekben és számos kisebb-nagyobb térségben is jellemző a gazdagság és szegénység éles térbeli elválása, csoportosulása, s „,közepes” fejlettségủ terek szükülése. Mindez - megítélésem szerint kissé eufémisztikus módon - egyfajta sajátos konvergenciaként is értelmeződik, az ún. konvergencia-klubok fogalmában: az egymástól távolodó, polarizálódó terekben az egyes lokális pólusok elemei ugyanis valóban egyre inkább hasonlókká válnak egymáshoz. A konvergencia-klub jelenséget sokan a Solow-modell „müködése” 
Nemes Nagy József : Kvantitatív társadalmi térelemzési eszközök a mai regionális tudományban.

Tér és Társadalom 21. évf. 2007/1. 1-19. p.

bizonyítékaként interpretálják, hisz a fentiek tükrében tényleg arról van szó, hogy az egyéb feltételek (a ,stacioner állapotok") tekintetében is vélhetöen hasonló téregységek, országok fejlettségi szintje közelít egymáshoz (igaz ez pusztán a gazdagoknak a gazdagokhoz, a szegényeknek a szegényekhez való hasonulását jelenti, a két csoport közötti olló szüküléséről nincs szó) ${ }^{8}$.

\section{A földrajz „számít”: térparaméterek, földrajzi determinációk}

A térbeli tagoltság nyilvánvaló jelenlétén, nagyságának, változásának mérésén túlmenően tanulmányok sokasága foglalkozik azzal, hogy vajon a "térbeliség" önmagában mekkora szerepet játszik mindebben?

Módszertani szempontból itt már sokszor átlépnek a vizsgálatok a területi statisztikai közelítésröl a térstatisztikai szemlélethez és eszköztárhoz. A kérdésre a jellegadó módszertani választ azok a (többváltozós) regressziószámítást használó publikációk adják, ahol a magyarázó változók jellemzően fekvési térparaméterek, illetve - kissé kibővítve a geográfia irányába a társadalmi jelenségek területi tagoltságának hátterében meghúzódó adottságokat és mechanizmusokat - különböző (természet)földrajzi sajátosságok. A témáról átfogó áttekintést tartalmazó egyik újabb tanulmány (Abreau et al. 2005a), szétválasztja az ún abszolút helyzetet (tulajdonképpen a "helyeket") és a relatív helyzetet leíró változókat?. Elöbbibe lényegében a természetföldrajzi jellemzők, valamint a fekvési és méretparaméterek, utóbbik közé pedig a közelséget, elérhetőséget többféle módon mérő változók tartoznak. Az első közelítés alapkérdéseit itt két egyszerü, saját számítási eredménnyel igyekszem érzékeltetni (az adathátteret itt is a korábbiakban már említett szubnacionális szintü adatgyüjtés képezte), A második változócsoport szerepére és sajátos tartalmú felértékelódésére a következỏ fejezet tér $\mathrm{ki}^{10}$.

A hely globális szinten sok tanulmányban szerepel a mintavételi pontok földrajzi koordinátáival azonosítva. A globális fejlettségi tagozódásnak inkább szimbolikus, mint szószerinti alapmodellje a sokat emlegetett „Észak-Dél” ellentét, a precízebb azonosításra azonban sokkal inkább a földrajzosabb „,Forró-Mérsékelt" megosztás alkalmas (1. ábra), hisz a konkrét számításokban a déli félteke újvilági centrumai (Ausztrália, Új-Zéland) ,északinak" minősülnek A földrajzi szélesség, mint egyszerủ magyarázó változó a fejlettségi tagozódásnak jelentős részét (közel harmadát, lásd $\mathrm{R}^{2}$ ) magyarázza a regressziós modellben.

Ez, a keresztmetszeti elemzésekben figyelemre méltóan magas arány érdemi interpretációja azonban nagy óvatosságot kíván. Számos éles vitacikk szól arról, hogy a földrajzi tényezőket elötérbe toló (üj)determinista álláspont (Mellinger-SachsGallup 1999) elfedi, földrajzi köntösbe öltözteti a konkrét társadalmi hatótényezöket, történetileg a gyarmatositás (Cogneau-Guenard 2002), aktuálisan pedig a globalizáció kizsákmányoló és erősen tagoló karakterét. A globalizáció - itt nem részletezhető hatásait elemző munkák arra utalnak, hogy a gazdasági nyitás/nyitottság az alacsony fejlettségủ országokban növeli a belső polarizáltságot, míg a fejlettebbekben épp az elzárkózás konzerválja az egyenlötlenségeket (Hegre et al. 2002). 
Nemes Nagy József : Kvantitatív társadalmi térelemzési eszközök a mai regionális tudományban.

Tér és Társadalom 21. évf. 2007/1. 1-19. p.

Kisebb léptékủ terekben, egy kontinensen belül a hely, a fekvés más paraméterei is megjelennek. Gallup (2000) a hasonló tartalmú latin-amerikai tanulmányokat értékelve " nagyon meggyőző adatokat sorakoztat fel olyan eredményekre, miszerint a kontinens számos országában (Bolívia, Kolumbia, Mexikó, Peru és Brazília utóbbiról külön lásd még Azzoni et al. 2000) a jövedelmek, az életviszonyok és a gazdasági fejlettség területi differenciáltsága rendkívül erős (esetenként kétharmados, háromnegyedes) magyarázó erővel írható le különböző fekvési térparaméterekkel és földrajzi jellemzőkkel (horizontális és magassági pozíció, éghajlati, ökológiai jegyek $)^{12}$. Az oroszországi szegénységi arányszámok területi különbségeinek tesztelésekor Koleinikov és Shorrock (2003) ugyancsak szerepeltet klimatikus viszonyokat jellemzö hőmérsékleti adatot, de fekvési (határmentiség, tengerparti fekvés) és településföldrajzi jellemzöket is (népsủrüség, nagyvárosok közelsége) a magyarázó változók között. Itt az eredmények nem utalnak a „földrajzi” tényezők olyan markáns és egyirányú súlyára mint az elöbbi példákban ${ }^{13}$.

Lássunk egy egyszerü európai példát is! Európában közismert a kontinens alapvető centrum-periféria megosztottságát egydimenziósító „Nyugat-Kelet” lejtö, a fejlettségnek a hellyel, az abszolút lokalizációval való magyarázata. Bár nem borul fel az alapreláció, de a (gyakorta megspórolt) konkrét számszerü vizsgálat ebben az esetben is finomítja a duális modellt (2. ábra), összetettebb társadalmi domborzat jelenlétét feltárva. A közölt modellben a fekvés magyarázó ereje különösen erös (közel háromnegyedes). A számszerüsített egyszerü térparaméter (földrajzi hosszúság) háttére itt is elgondolkodásra késztet, bár az égtáji megnevezések a "nyugatias” vagy „keleties” fejlödéstörténetben, kulturális, mentális gyökerekben markánsabbnak tünnek, mint a globális példa Észak-Dél dualitása. A konkrét európai példa alaptendenciájában illeszkedik a más kontinensek esetében nagyon markáns s ezért gyakorta használt magyarázó faktor ( $a z$ óceánoktól való távolság) és a fejlettség negatív összefüggéseibe. Európa vizsgált zónájában azonban egy sajátos paradoxont is felfedezhetünk - a svájci és osztrák jövedelmi csúcs azt is sugallhatja, hogy a magashegységi karakter jövedelemgeneráló hatású, miközben szinte minden más szegletében a világnak épp fejlettségi, fejlödési fék.

Az e modellekben szereplő fekvési, helyzeti jellemzők nem pusztán a fejlettségi térsémák megértésének fontos háttérváltozói, hanem nagyonis mindennapi elỏnyök és hátrányok forrásai. Hausman és szerzőtársai (2005) például azonos termékcsoportot érintö importügyletek adatait feldolgozva kimutatták, hogy ugyanazon gazdasági fejlettségi szint mellett a megrendeléstöl a célba érkezésig eltelt idő a szárazföldi (landlocked) fekvésủ országokban kétszer olyan hosszú, mint a tengerpartiakban. Ilyen konkrét hátrányok, veszteségek is meghúzódnak abban a relációban, amit egy, a fejlödỏ világ országaira végzett összehasonlító elemzés (Snow et al. 2003) meggyözően igazol, miszerint a kontinensek belső térségeiben fekvö országok fejlettségi mutatói tendenciózusan rosszabbak tengerparttal rendelkező szomszédaikénál. Az ENSZ szakértöi által készített tanulmány a HDI-t és komponenseit veti össze az említett országcsoportokban. Minden HDI-komponensben, s minden kontinensen egyértelmü a tengerparttal rendelkező szomszédok elönye. Egyetlen, a szabályt erösítö kivétel azért van, Belsö-Ázsia volt szovjet tagállamai a képzettségi komponensben megelözik fekvési szempontból szerencsésebbnek látszó, aktuális állapotaikat tekintve egyébként korántsem ideális helyzetü szomszédaikat. 
Nemes Nagy József : Kvantitatív társadalmi térelemzési eszközök a mai regionális tudományban.

Tér és Társadalom 21. évf. 2007/1. 1-19. p.

A két ábrával és a szakirodalmi utalásokkal érzékeltetni kívánt közelítés a tér (a fekvés) és társadalom (fejlettség) kapcsolatára a „tér” szerepére, hatásaira koncentrálva keresi a választ. Ez a logika megengedhető, de az eredmények durván leegyszerüsítőek, ha nem egészítjük ki modelljeinket társadalmi tartalmú változókkal. Mindezért a mélyebb magyarázatokra törekvő tanulmányokban, számításokban természetesen társadalomszerkezeti indikátorok is helyet kapnak a területi különbségek magyarázatában (a hazai térszerkezet tagoltságát vizsgáló kutatásainkból ezt példázza Nemes Nagy-Németh 2003).

Míg a regionalisták, geográfusok kutatásaiban - bár a figyelem jellemzően a területi sokszínüségre, tagoltságra irányul - fel sem merül a konkrét társadalmi hatóerök figyelmen kívül hagyása, a legutóbbi időkig sokkal kevésbé volt magától értetődó az, hogy a társadalmi tagozódás magyarázatához nem elégségesek a "térmentes" társadalmi indikátorok. Nagy fordulat a tágabb társadalomelemzésben épp abban látszik manapság, hogy polgárjogot nyernek azok a közelítések, amelyek az explicit térbeliséget, a közelség, az egymásmellettiség, a térbeli konfiguráció (Abreau és szerzötársai említett osztályozásában a „relatív helyzet”) hatásait is bevonják a vizsgálatokba. A következőkben erröl szólunk.

\section{1. ÁBRA}

A világméretü „Észak-Dél" tagolódás: a gazdasági fejlettség és a földrajzi pozíció kapcsolata szubnacionális egységek adatai alapján

(The "North-South" Development Divide, the Relation of Development Level and Lattitudial Position on Subnational Level at the Millenium)

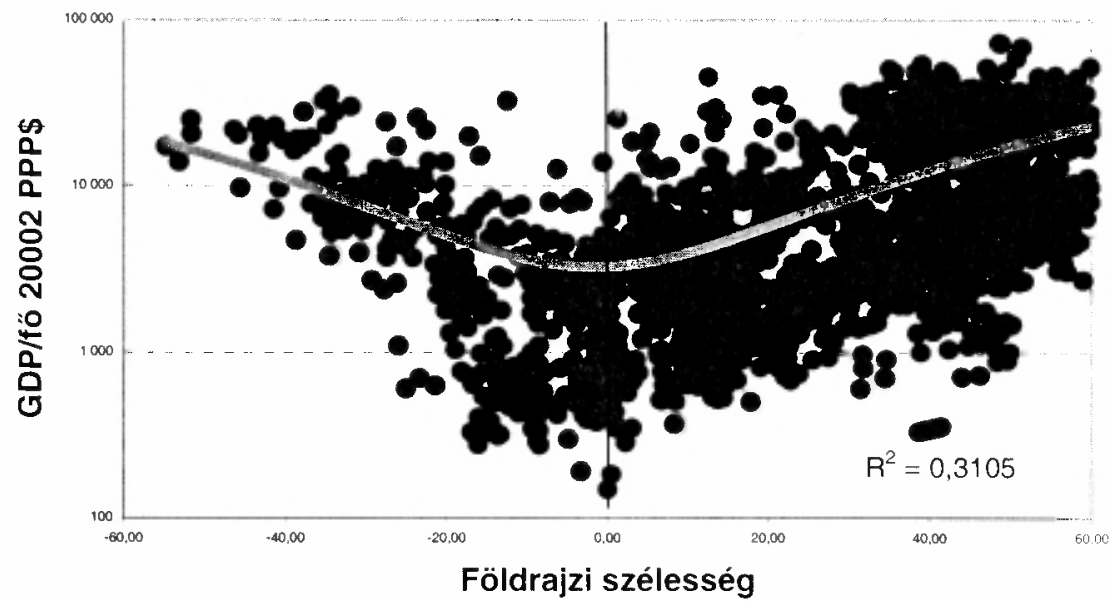

Forrás: A szerző adatgyưjitése és számításai alapján. 
Nemes Nagy József : Kvantitatív társadalmi térelemzési eszközök a mai regionális tudományban.

Tér és Társadalom 21. évf. 2007/1. 1-19. p.

TÉT XXI. évf. 2007 a 1 Kvantitativ társadalmi térelemzési ... 11

\section{2. ÁBRA}

Nyugat-Kelet fejlettségi keresztmetszet Európában az ezredfordulón Budapest szélességi zónájában, regionális adatok alapján

(West-East slope in Europe, Regional GDP/capita Level and Longitudial Position in zone of Budapest)

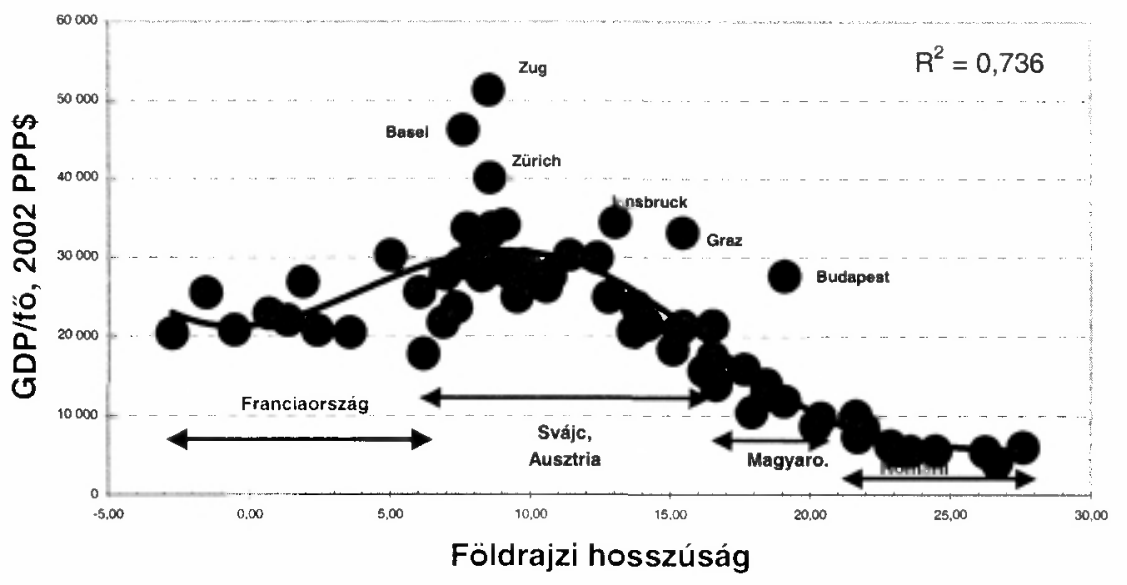

Forrás: A szerzö adatgyüjtése és számításai alapján.

\section{A spaciális - speciális?!}

A területi problémák $\mathrm{s}$ ennek következtében a területi (lokalizált) adatokkal végzett számítások jól érzékelhetỏ előtérbe kerülése a legkülönbözőbb tudományterületeken kettős következménnyel jár.

Egyrészt, az egyre gyakoribb területi elemzések következtében mindezen vizsgálatok egyre hétköznapibbá válnak, $\mathrm{s}$ a feldolgozásuk során használt kvantitatív elemzési eszköztár az általános statisztika generális módszertanából és szemléletéböl táplálkozik. E szemléletben a spaciális (a térbeli) egyáltalában nem számít speciálisnak.

Ez vezet aztán - egyebek mellett - az alapvetó „tévúthoz" a minta és populáció fogalmának és használatának viszonyában a területi társadalomstatisztikai kutatások során. Azt, hogy mintaként kezelik és statisztikailag így elemzik az annak nem tekinthető területi adatsorokat is, kimerítỏen és érdemben elemzi figyelemre méltó tanulmányában a kvantitatív térelemzés egyik legfelkészültebb hazai képviselöje, Dusek Tamás, rávilágítva a leíró statisztikai eszköztáron túli különbözỏ eszközök pl. a szignifikancia-vizsgálatok - „precíznek" és meggyőzőnek látszó, de itt teljességgel funkciótlan használatára (Dusek 2006, 233-239).

A másik messze ható elméleti és módszertani következményekkel járó vonulat ellenben épp a „spaciális” igenis „speciális” összefüggést emeli ki. E reláció középpontjában a ma már nálunk is közismert területi autokorreláció fogalma és mérési 
Nemes Nagy József : Kvantitatív társadalmi térelemzési eszközök a mai regionális tudományban.

Tér és Társadalom 21. évf. 2007/1. 1-19. p.

eszköztára áll (lásd Dusek 2004), konkrét számítási metódusokra lefordítva a ,földrajz elsö törvényeként” ugyancsak gyakorta idézett mondatot: „Minden mindennel összefügg, de az egymáshoz közeli dolgok egymásrahatása erösebb" (Tobler 1970).

Az autokorrelált területi adatok statisztikai módszertana kidolgozásának vezetö alakjai amerikaiak. Közöttük egyaránt találhatunk „kvantitatív geográfusokat” (a legnevesebb közülük talán Arthur Getis, a San Diegoi Egyetemröl, az egyik nagyon korai, még a geográfia kvantitatív forradalmát idéző térelemzó munka társszerzője: Getis-Boots 1978). A közgazdasági indíttatású téranalízis vezető alakja, a széles körben használt SpaceStat, GeoData programok megalkotója Luc Anselin az Illinois Egyetem professzora, első átfogó munkája 1988-ban jelent meg, s azóta is folyamatosan publikál a témakörben (Anselin 1988, 2006; az anselini iskoláról lásd Varga 2002).

Térszemléletét és elemzési eszközrendszerét tekintve ugyancsak a területi autokorreláltság az egyik sarokpontja a korábbiakban említett CSISS körüli kutatói gondolkodásnak is. A tágabb társadalomkutatási hatókörre való kiterjesztés jeleként itt - sok egyéb következményen túl - a Tobler-törvény már a kognitív vagy mentális geográfia szemléletére is lefordítódik. „Az emberek az egymáshoz közeli dolgokat hasonlóbbnak gondolják (mint a távoliakat)" - írja és nevezi ezt a Kognitív Geográfia Első Törvényének egyik prezentációjában M.F. Goodchild, D.R. Montello s S.R. Fabrikant munkáira hivatkozva (Goodchild 2003).

A területi autokorreláltságot mérỏ számos mutatószám közül legelterjedtebb, közismert mutatószáma a Moran féle autokorrelációs együttható (I). Ez tetszöleges társadalmi indikátorral számolva azt méri (elméletileg -1 és 1 közötti intervallumba eső értékekkel), hogy a vizsgálati alapegységek (térrészek) és a hozzájuk közeli (leggyakrabban a velük szomszédos) területegységekben az adott jelenség együtt mozog-e (pozitív területi autokorreláltság) vagy épp ellentétes, mozaikszerü a megjelenése (negatív területi autokorreláltság), netán ilyen határozott kapcsolat nincs. A mára megsokasodott empirikus eredmények egyértelmúen igazolják, hogy ezen elméletileg lehetséges esetek közül a társadalmi jelenségekre a pozitív területi autokorreláltság a jellemző.

A területi autokorreláltság e „globális” (a vizsgált térrészen jelen lévő konfigurációt egyetlen korrelációs indexszel jellemzö) mutatószámához képest geográfiailag jóval szemléletesebb eredményeket adnak az ún. lokális autokorreláltságot (Anselin 1995) ábrázoló térképek (3.ábra).

Ezeken a vizsgálati egységek és szomszédaik adott jelzőszám szerinti egyszerủ osztályozása látható (a térképek hangsúlyozottan nem az egyes kistérségek jövedelemszintjét, hanem azok és szomszédaik együttes jövedelmi pozícióját ábrázolják!). Minden területegységet be kell sorolni aszerint, hogy a vizsgált indikátor ott, illetve a szomszédokban milyen értéket vesz fel, s így négy alaptípus adódik. A közölt térképeken az elsö típust az átlag feletti jövedelmủ és egyben átlag feletti jövedelmú szomszédokkal rendelkezö térségek adják $(\mathrm{HH})$, a helyi magas jövedelem párosulhat a szomszédok alacsony jövedelmeivel és fordítva (HL és LH), s elöfordulnak olyan térrészek, ahol mindkét érték átlag alatti (LL). 
Nemes Nagy József : Kvantitatív társadalmi térelemzési eszközök a mai regionális tudományban.

Tér és Társadalom 21. évf. 2007/1. 1-19. p.

TÉT XXI. évf. 2007 - 1

Kvantitatív társadalmi térelemzési ... 13

\section{3. ÁBRA}

Az egy före jutó adóköteles jövedelmek lokális (kistérségi) autokorreláltsága 1990-ben (fenn) és 2003-ban (lenn)

(Local Autocorrelation Pattern of Teaxble Income Level in Hungary, 1990, 2003)
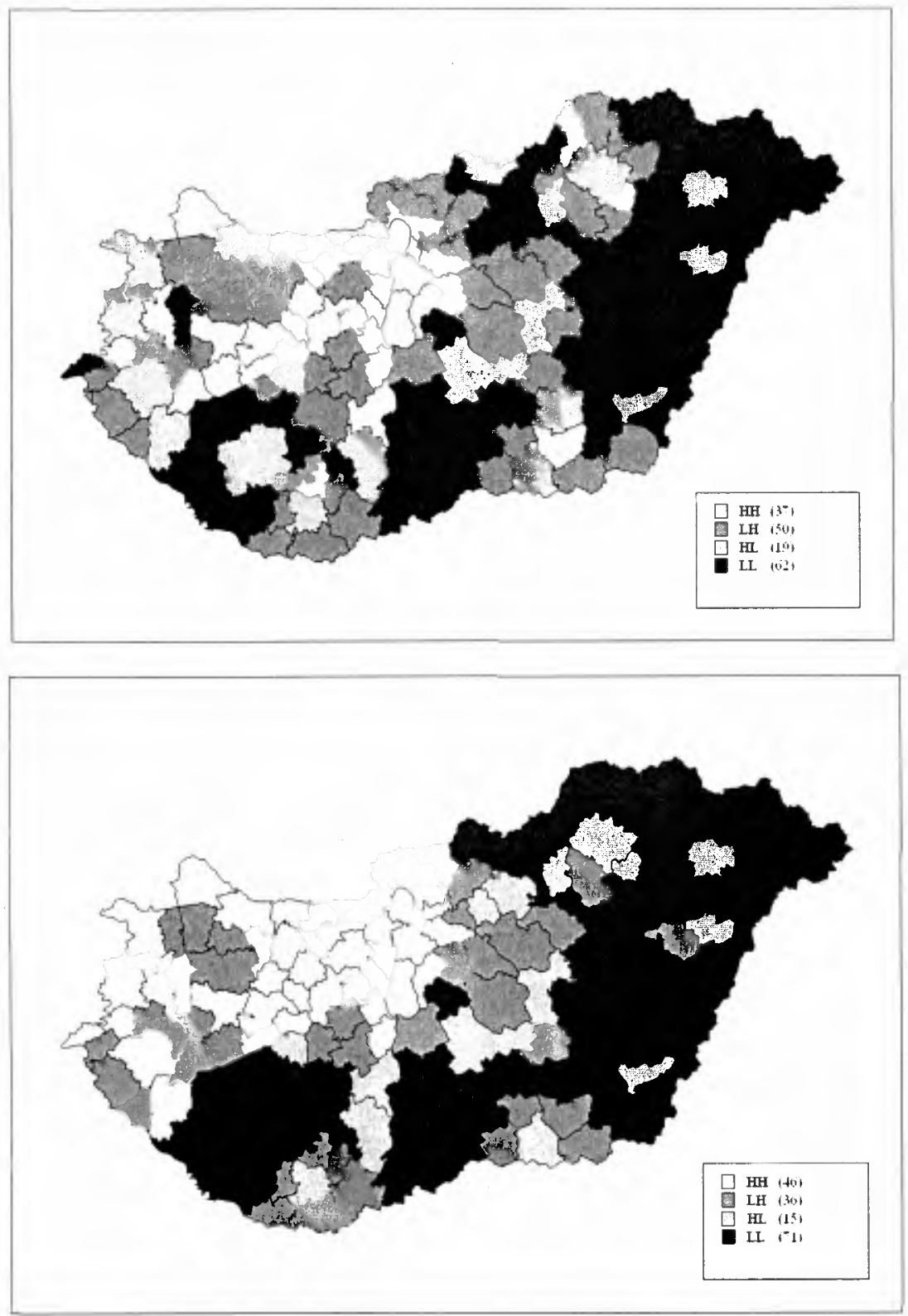

Forrás: Löcsei Hajnalka számításai és szerkesztése. 
Nemes Nagy József : Kvantitatív társadalmi térelemzési eszközök a mai regionális tudományban.

Tér és Társadalom 21. évf. 2007/1. 1-19. p.

$14 \quad$ Nemes Nagy József

TÉT XXI. évf. 2007

A közölt térképeken jól érzékelhetö, hogy hazánkban az elmúlt évtizedben milyen határozottan „letisztult” a jövedelmi tér, a kilencvenes évek eleji mozaikszerüség (a HL és LH kombinációk viszonylag nagy száma) nagyon visszaszorult. Mindez világos térbeli megjelenése a regionális differenciálódás, illetve polarizáció markáns trendjének.

A metódus természetesen jelen van a nemzetközi szakirodalomban is. A „,klubosodó” világ térfolyamataiban ugyancsak erös területi autokorreláltság mérhetỏ (Shin 2002, másokhoz hasonlóan - a tér- és idömentes világ eljövetelét hirdetökkel szemben - kiemelt fejezetcímben jelzi: „Meghalt a távolság. Éljen a távolság!") Európa jövedelmi autokorreláltsági sémájáról a legújabb publikációk közül lásd Feldkircher 2006, az USÁ-n belüli jövedelmi folyamatokról pedig Lim 2003 tanulmányait. Az amerikai elemzések - a másutt (lásd a magyar esetet) inkább jellemzö trenddel szemben - arra utalnak, hogy itt a századvégen kissé újra növekvö területi jövedelmi differenciáltság csökkenő területi autokorreláltsággal párosult. Ez azzal függ össze, hogy az új dinamika tere itt nem a két korábbi kiugró fejlettségü partvidéki (atlanti és kaliforniai) régió, hanem, mozaikos formában ugyan, de elsődlegesen a feltörekvö Dél.

\section{Új regressziós filozófia a területi kutatásban}

A társadalmi jelenségek jellemző térbeli autokorreláltsága nemcsak kínál új elemzési utakat, hanem követel is új elemzési eszközöket. Az alábbiakban az új regreszsziós filozófia föbb elemeit, lépéseit foglalom össze (a finomabb részletek megismeréséhez a szakirodalom tanulmányozása, s konkrét számítási kísérletek javallottak). Fontos hangsúlyozni, hogy itt jellemzően egy olyan logikájú és követelményrendszerú lépéssorozatról van szó, ami a „térhatás”, a térbeli autokorreláltság mechanizmusairól semmit sem árul el (ezek feltárása egy újabb, kevésbé statisztikus karakterü kutatási szakaszt feltételez), ellenben a számításokat matematikaistatisztikai szempontból korrekté teszi.

A „térmentes" regresszióelemzés jól ismert modellje az ún. OLS (Ordinary Least Squares - hagyományos legkisebb négyzetek módszere), amelyet területi megfigyelési egységekre vonatkozó adatokkal is használnak. A modellben $Y_{i}$ a függö (magyarázni kívánt, magyarázott), $X_{\mathrm{ij}}$ a független (magyarázó) változók vektorai, $\mathrm{u}_{\mathrm{i}}\left(\right.$ majd $\varepsilon_{\mathrm{i}}$ ) a hibatag (reziduum), $\beta$ (majd alább $\gamma, \lambda$ ) a regressziós együtthatók, a képletekben az alsó indexekben i a megfigyelési egységeket, $\mathrm{j}, \mathrm{k}$ a változókat azonosítja.

$$
\mathrm{Y}_{\mathrm{i}}=\mathrm{X}_{\mathrm{ij}} \beta_{\mathrm{j}}+\mathrm{u}_{\mathrm{i}} \quad(\mathrm{OLS})
$$

E modell használatakor - föként a keresztmetszeti elemzések során - elsöre szinte sohasem sikerül erös magyarázóerejủ (nagy determinációs együtthatójú) modellt megkonstruálni, a hibatag súlya nagy marad. A kutató elött áll a modell ,javításának" gondja. A korrekció újabb magyarázó változók bevonásával kísérelhető meg még mindig figyelmen kívül hagyva bármifajta sajátos térbeliséget.

A változóbővítés logikája mentén koncepcionális ugráshoz már egy kissé munkaigényesebb fázis is szükségeltetik: térképezzük eredményeinket, a becsült értékeket, illetve a hibatagot (megtehetjük, hisz területi megfigyelési egységekre vonatkozó 
Nemes Nagy József : Kvantitatív társadalmi térelemzési eszközök a mai regionális tudományban.

Tér és Társadalom 21. évf. 2007/1. 1-19. p.

adatokkal dolgozunk). Ezt végrehajtva, esetenként arra figyelhetünk fel, hogy a hiba, a reziduum sajátos térbeli elrendeződést, konfigurációt mutat, nem véletlenszerü, hanem sajátos földrajzi eloszlású (zonális, koncentrált vagy más jellegzetes elrendeződésú). Ezt felismerve jöhet a modell újszerü javítása, új, de már kifejezetten területi jegyeket tuikrỏzó magyarázó változó(k) bevonása a számításba.

Létrejön az újabb modell az ún. Fixed/Random Effects Modell (FEM vagy REM), ahol az új változó $D_{i k}$ - tipikusan valamilyen földrajzi sajátosságot, térrészhez tartozást leíró (0 és 1 értékkészletü) dummy változó. (Ha a térképezésben valamely településcsoport, régió, sajátos országcsoport, kontinens reziduális értékei markánsan nagyok vagy kicsinyek, akkor az alapegységeknek e térséghez tartozását kell azonosítani ezzel.) Ha az újabb futtatás eredményeként javul a magyarázóeró és a dummy szignifikánsnak minősül a vizsgált jelenség differenciáltságának magyarázatában, ez önálló hatótényezöként megjelölhető (pl. ,alföldiség”, „francia gyarmati múlt”, „,kikőtővárosi jelleg”, „,kiemelt fejlesztési övezethez tartozás” - megnevezésekkel).

$$
\mathrm{Y}_{\mathrm{i}}=\mathrm{X}_{\mathrm{ij}} \beta_{\mathrm{j}}+\mathrm{D}_{\mathrm{ik}} \gamma_{\mathrm{k}}+\varepsilon_{\mathrm{i}} \quad \text { (FEM, REM) }
$$

A területi adatokkal végzett OLS-modellek ,javításának" további útjai már nem vizuális tapasztalaton, hanem konkrét számításokon alapulnak, mégpedig azon logika mentén, hogy kiküszöbölendö (csökkentendö) a hibatagnak a területi autokorreláltsága, az OLS modellnek ugyanis elvi feltétele a hibatag függetlensége. Ennek hiányában a modell szisztematikusan felül-, illetve alulbecsüli a függő változó értékeit a különbözö térrészeken.

A modellkorrekció (a területi autokorreláltság figyelembevétele) két úton lehetséges. Egyrészt oly módon, hogy bỏvítjük a magyarázó változók körét egy új, a függö változó adataiból számítható - rossz fordítással „térben késleltetett" - változóval, (Spatial Lag Model-SLM). Ennek megkonstruálásakor lép be a számításba a területi autokorreláció kapcsán már említett szomszédsági relációkat számszerüsítô, ún. szomszédsági mátrix ${ }^{14}(\mathrm{~W})$. A szomszédsági mátrix és a fủggỏ változó szorzataként adódó új változó - egyszerüen fogalmazva - a függő változóként szereplő indikátornak minden megfigyelési egységre vonatkozóan a szomszédos területegységekre számított átlagos értékét tartalmazza (ha például az egy före jutó jövedelmet magyarázzuk, akkor minden téregységhez a vele szomszédos területek átlagjövedelme rendelödhet). A korrekció akkor eredményes, ha megszünik a hibatag területi autokorreláltsága.

$$
Y_{i}=X_{i j} \beta_{j}+W Y_{i} \gamma+\varepsilon_{i}
$$

A máig kidolgozott másik korrekciós lehetőség az ún. Spatial Error Model $(S E M)$, a regressziós összefüggést úgy javítja, hogy új változóként a hibatag ,térben késleltetett" értékeit vonja be új magyarázó változóként a modellbe:

$$
Y_{i}=X_{i j} \beta_{j}+\lambda W u_{i}+\varepsilon_{i}
$$

E térstatisztikai, térökonometriai közelítések, modellek ma egyértelmủen uralják a kvantitatív térszerkezeti, regionális egyenlőtlenségi vizsgálatokat a nemzetközi szakirodalomban, a publikációk növekedése az utóbbi években exponenciális jellegű. 
Nemes Nagy József : Kvantitatív társadalmi térelemzési eszközök a mai regionális tudományban.

Tér és Társadalom 21. évf. 2007/1. 1-19. p.

Az empirikus alkalmazások mellett folyamatos a módszertan finomítása, alakítása is (Cheshire-Magrini 2006; Aldstadt-Getis 2006).

Ez a modellsor, illetve a tanulmány többi fejezetében jelzett közelítések a nemzetközi regionális elemzési szakirodalom és a kapcsolódó felsöfokú képzések standard eszköztárába tartoznak. Ismeretük alapfeltétele ma már szinte minden releváns kvantitatív térelemzési munka megértésének is, használatuk, kipróbálásuk az egyik aktuális módszertani kihívás a hazai regionális kutatók szélesebb köre számára is.

A fö elemeiben bemutatott elemzési eszköztár formális, statisztikai tartalmát tekintve „skálafüggetlen”, a vizsgálati egységek lehetnek egyedi helyek éppúgy, mint városi szomszédsági egységek, kistérségek vagy nagyobb régiók. Tartalmuk, jelentésük végiggondolása során azonban érdemes mérlegelni, hogy a „földrajz elsö törvénye" vajon milyen léptékben, térségi szinten vehető igazán komolyan (azaz nem túlságosan leegyszerüsítően).

A jól ismert társadalmi tapasztalatok, miszerint: „suba subához, guba gubához”, "gazdagnak gazdag, szegények szegény a szomszédja", a mikroszintủ és a belső társadalmi térbeli egymásrahatásokat valóságosan meglévőnek jelzik. Magasabb területi aggregációkban azonban jóval összetettebbek az e modellekkel jól, de mégis csak leegyszerüsítetten érzékeltethetö kölcsönhatások. A Nyugat-Dunántúl dinamikája például nem a vele közvetlenül szomszédos osztrák térségek direkt hatásának köszönhető (annak is), hanem egy tágabb fejlett tér közelségének, illetve az onnan induló impulzusok befogadására alkalmas helyi viszonyoknak. (Az ilyen nehezen számszerüsíthető körülmények indikátora lehet a modern technológia átvételében például a külföldi beruházó nyelvének ismerete - Keller 2001 -, ami felerősítheti vagy épp lecsökkentheti a „,közelség” kapcsolatgeneráló erejét.) Igaza van azoknak a szerzöknek is, akik - ugyan az egész "területi” szakmát is megtisztelő módon e térelemzési modellek használatakor azok geográfiai magját hangsúlyozva - arra is felhívják a figyelmet, hogy a térbeli egymásmellettiség általánosabb társadalmi, hatalmi, kulturális tartalmakkal s következményekkel telítödve hat (Beck-Gleditsch 2003).

Végülis mindezek ugyanahhoz az elvi súlyú gondolathoz visznek vissza bennünket, amit már a tanulmány elején is hangsúlyoztam: a kvantitatív elemzés, a térhatás modellezése egy olyan kutatási szemléletben lehet értékes és hasznos, amely figyelembe veszi a konkrét földrajzi és társadalmi feltételeket és mechanizmusokat is. Ez nem ismeretlen szemlélet: ez a modern regionális tudomány szemlélete.

\section{Jegyzetek}

'A tanulmány a Fiatal Regionális Kutatók Fórumán, 2006 novemberében Kecskeméten, az MTA RKK Alföldi Tudományos Intézetében tartott előadás anyagára épül.

${ }^{2}$ Ennek egyik elemeként említi Nagy Gábor jelen számban közölt tanulmánya a földrajz meghatározó iskoláinak elfordulását a területi modellektöl (a hetvenes években), a magam tapasztalatai szerint azonban az elfordulást, más meghatározó iskolákban legújabban egy markáns visszafordulás kôveti, a teljesen új eszközök és felismerések birtokába jutott kvantitatív módszertan bázisán.

3 A társadalmi tértudományi közelítés mára nevezéktanában is legalitást nyert és intézményesült, az új központ ugyancsak amerikai: az M. F. Goodchild vezetésével múködỏ CSISS (Center for Spatially Integated Social Science) a Santa Barbara-i székhelyü Kaliforniai Egyetem keretében. Itt az isardi regionális tudomány már az egyik elökép, részterület szerepében bukkan fel. (Információk errỏl: www.csiss,org.) 
4 Nem titkoltan ezt (s nem a kvantitatív közelítés bármifajta kizárólagosságának igazolását) célozta a 2006 öszén, az ELTE-n megrendezett Regionális modellek c. konferenciánk, amelynek több előadása e folyóiratszámban olvasható.

${ }^{5}$ Erröl lásd jelen lapszámban Jakobi Ákos tanulmányát.

${ }^{6}$ A terủleti kutatások tematikai súlypontjainak változásában sajátos fogalmi innováció sorozat is felismerhetỏ. Egymást váltva uralják el egy-egy időszakban a publikációkat az erỏs átfedésben, rokonságban lévô fogalmak (urbanizáltság, fejlettség, innovativitás, versenyképesség). E fogalmak bevezetésekor, elméleti leírásakor ugyan jellemzöen küilönbözőségeikre kerül a hangsúly, de amikor az empirikus vizsgálatra kerül a sor, kísértetiesen hasonló mutatórendszerekkel mérik (tudják mérni) a korábban hangsúlyozottan kủlönbözőnek tételezett tartalmakat. Ennek következményeként az eredmény magától értetỏdően nem más, mint az, hogy az urbanizált, fejlett, innovatív, versenyképes térségek általában ugyanazok lesznek, s e jegyek hiánya is ugyanazon térségi kört jelöli ki.

${ }^{7}$ A szélsőértékek összevetése természetesen csak egyik mutatója a területi tagoltságnak, aminek értékeit leginkább két régiótípus, valamely kiugróan magas fejlettségủ centrumterület vagy ásványkincs (ma jellemzóen a kóolaj) kiaknázásából származó extrajỏvedelem jelenléte vagy hiánya befolyásolja. (Az egy före jutó GDP-nek az adatbázisból számítható világátlaga 7800 dollár.)

8 A kapcsolódó szakirodalom itt nem részletezhető további módszereket is bevet az egyenlötlenségek alakulásának vizsgálatakor. Többeknél felbukkan például a Markov láncok alkalmazása, erröl lásd Major Klára tanulmányát e számban.

9 9 A hazai geográfusoknak bizonyára ismerösen cseng ez a kettoosség, Mendöl Tibor jól ismert kategóriaiit idézi.

10 A nagy tradíciójú, máig virulens modellek közül e közelítéshez sorolhatók a fizikai analógiákon alapuló egymásrahatási modellek, köztuik a jelen számban Tagai Gergely által mérlegre tett potenciálmodell is (elsődlegesen annak az elérhetőség komplex mérésére való használata kapcsán).

A nemzetközi szakirodalom tükrében - a világméretủ közelítések mellett - a talán legtartósabban megosztott kontinensröl, Latin-Amerikáról található a legtöbb komoly elemzés a fejlödés és a fejlettség, valamint a földrajzi faktorok közötti kapcsolatról.

12 A földrajzi (természeti, társadalomföldrajzi, helyzeti-elérhetőségi) tényezók vizsgálatba vonásával a szegénység magyarázata túllép az egyéni, kisközósségi belsö korlátokra és fékekre leszükülö magyarázaton. A földrajzi adottságok lassú változása, immobil jellege ezeket a társadalmi polarizáció egyik legnehezebben kiküszöbölhetó tényezőjévé teszik, a kedvezötlen helyi adottságokra gyakran egyetlen válasz ígér potenciális esélyeket: az elköltézés a jobb körülményeket ígérỏ terekbe.

${ }^{13} \mathrm{Ez}$ a tanulmány a helsinki székhelyü WIDER (World Institute of Development Economic Research) konferenciájára készült. Ez az intézet (tk. egy nemzetkőzi hálózat kis apparátusú központja) ma a globális és regionális egyenlötlenség-kutatások egyik elsörangú centruma, kiemelt szakmai és politikai érdeklödésre számot tartó rendezvények és kutatások iniciátora.

${ }^{14}$ Ez egy olyan négyzetes mátrix, aminek soraiban és oszlopaiban egyaránt területegységek szerepelnek. A cellaérték - alapesetben - 0 a nem szomszédos egységek esetén és a fóátlóban, s 1 a szomszédok közös celláiban. Ebböl számítható az ún. sornormált mátrix, amelyben az induló mátrix celláinak értékeit a sorösszeggel osztjuk. Ha egy térségnek pl. 5 szomszédja van, akkor ennek sorában $1 / 5$ lesz az érték. A cellaértékek más, a szomszédságot, a távolságot érzékeltetô számadatok is lehetnek, például a téregységek távolságának vagy a távolságok négyzetének reciprokai, az ún. inverz-távolságok.

\section{Irodalom}

Abreau, M.-de Groot, H.L.F.-Florax, R.J.G.M. (2005a) Space and Growth: a survey of empirical evidence and methods. - Région et Dévelopement, 21. 13-44. o.

Abreau, M.-de Groot, H.L.F.-Florax, R.J.G.M. (2005b) A Meta-Analysis of Beta-Convergence. - Tinbergen Institute Discussion Paper. 3.

Aldstadt, J.-Getis, A. (2006) Using AMOEBA to Create a Spatial Weights Matrix and Identify Spatial Clusters. - Geographical Analysis. 4. 327-343. o.

Anselin, L. (1988) Spatial Econometrics: methods and models. Dordrecht: Kluwar Academic.

Anselin, L. (1995) Local indicators for spatial association-LISA. - Geographical Analysis. 27. 93-115. o.

Anselin, L. (2006) Spatial Analysis with GeoData. http://www.regroningen.nl/summerschool. 
Nemes Nagy József : Kvantitatív társadalmi térelemzési eszközök a mai regionális tudományban.

Tér és Társadalom 21. évf. 2007/1. 1-19. p.

18 Nemes Nagy József

TÉT XXI. évf. 2007

Azoni, C.R.-Menezes-Filho, N.-de Menezes, T.A.-Silveira-Neto, R. (2000) Geography and Income Convergence among Brazilian States. - Inter-American Development Bank Research Network Working Paper. 395. o.

Bangó J. (2006) A tér szociális konstrukciója, - Társadalomkutatás. 3. 379-401. o.

Barro R. (1988) Economic Growht in a Cross-section of Countries. - NBER Working Paper. 3120

Beck, N.-Gleditsch, K. (2003) Space is more than Geography. Joint Meetings of the European Consortium for Political Research. Edinburgh.

Benko, G. (1999) Regionális tudomány. Dialóg-Campus, Budapest-Pécs.

Boyce, D. (2004) A short history of the field of regional science, - Papers in Regional Science, 83. 31-57. o.

Cheshire, P.-Magrini, S. (2006) European Urban Growth: now for some problems of spaceless and weightless econometrics. Conference paper. 46th Congress of the European Regional Science Association. Volos.

Cogneau, D.-Guenard, C. (2003) Colonization, Institutions, and Inequality: A Note on Some Suggestive Evidence. - DIAL DT/2003/05.

Dusek T. (2004) A terileti elemzések alapjai. Regionális Tudományi Tanulmányok 10. ELTE, Budapest.

Dusek T. (2006) Területi statisztika, valószínüségszámítás és statisztikai következtetéselmélet - Területi Statisztika. 3. 223-239. o.

Ezkurra, R.-Gil, C.-Pascual, P. (2005) Regional Bipolarization: The Case of the European Union, International Journal of Urban and Regional Research. 4. 984-995. o.

Farkas J. (2003a) A társadalmi tér fogalma és mérési lehetőségei, - Társadalomkutatás. 1. 7-32. o.

Farkas J. (2003b) A társadalmi tér elméleti kérdései (A térfelfogás történeti változásai) - Társadalomkutatás. 2. 161-190. o.

Feldkircher, M. (2006) Regional Convergence within the EU-25: A Spatial Econometric Analysis. Österreichische Nationalbank, Workshops. 9. 101-119. o.

Gallup, J.L. (2000) Geography and Socioeconomic Development (www.cid.harvard.edu/andes/)

Getis, A.-Boots, B.N. (1978) Models of Spatiak processes: An Approach to the Study of Points, Lines and Area Patterns. - Cambridge University Press

Goodchild, M.F. (2003) The Fundamental Laws of GIScience. - Annual Assembly of the University Consortium for Geographic Information Science. Monterey, CA (www.csiss.org)

Haggett, P. (2006) Geográfia - globális szintézis. Typotex, Budapest.

Hausman, W.H.-Lee, H.L.-Subramanian, U. (2005) Creating Global Value Through Efficient Trade Logistic. - FIAS and Stanford University Global Logistics and Trade Competitiveness Conference. Washington.

Hegre, H.-Gissinger, R.-Gleditsch, N.P. (2002) Globalization and Internal Conflict. - Polarization and Conflict. Conference-paper. Barcelona.

Heshmati, A. (2006) The World Distribution of Income and Income Inequality: A Review of the Economics Literature. - Journal of World-Systems Research. 1.61-107. o.

Isard, W. (1956) Location and Space-Economy: A General Theory Relating to Industrial Location, Market Areas, Land Use, Trade and Urban Structure. The MIT Press, Cambridge, Massachusetts.

Isard, W. (1960) Methods of regional analysis. An Introduction to Regional Science. The MIT Press, Cambridge, Massachusetts.

Keller, W. (2001) The geography and channels of diffusion of world's technology frontier, - NBER Working Paper. 8150, Cambridge, MA.

Koleinikov, S.-Shorrock, T. (2003) Regional poverty in Russia: Is it geography or economics that matter? - WIDER Conference on Inequality, Poverty and Human-Well-Beeing. Helsinki.

Krugman, P. (1998) The Role of Geography in Development. - Annual World Bank Conference on Development Economics. Washington, D. C.

Lim. U. (2003) A Spatial Analysis of Regional Income Convergence. - Planning Forum. 9. 66-79. o.

Major K. (200I) A nemzetközi jövedelemegyenlôtlenségek dinamikája. PhD értekezés. BKÁE, Budapest.

Meggyesi T. (2002) A külsỏ tér - Építés-Építészettudomány. 1-2. 53-93. o.

Mellinger, A.D.-Sachs, J.D.-Gallup, J.L. (1999) Climate, Water Navigability and Economic Development. CID Working Paper. 24. 0.

Milanovic, B. (2002) True World Income Distribution, 1988 and 1993: First calculation based on household surveys alone. - The Economic Journal. January. 51-92. o.

Nemes Nagy J.-Németh N. (2003) A „hely” és a „fej”. A regionális tagoltság tényezöi az ezredforduló Magyarországán. - Budapesti Munkagazdaságtani Füzetek. 7. KTK.

Nemes Nagy J. (1998) A tér a társadalomkutatásban (Bevezetés a regionális tudományba) Hilscher Rezső Szociálpolitikai Egyesület, Ember-Település-Régió sorozat, Budapest.

Nemes Nagy J. (szerk.) Regionális elemzés módszerek. - Regionális Tudományi Tanulmányok. 2. ELTE, Budapest. 148. o. 
Nemes Nagy József : Kvantitatív társadalmi térelemzési eszközök a mai regionális tudományban.

Tér és Társadalom 21. évf. 2007/1. 1-19. p.

Nemes Nagy J. (2006) A regionális fejlettségi tagoltság keresztmetszeti összehasonlítása. - Hajdú Z.Györi R. (szerk.) Kárpát-medence: települések, tájak, régiók, térstruktúrák. MTA RKK, DialógCampus, Pécs-Budapest. 192-211. o.

Nordhaus, W. (et al.) (2006) The G-Econ Database on Gridded Output: Methods and Data, http://gecon.yale.edu/

OECD (2005) OECD Regions et a Glance. OECD Publishing, Paris.

Polèse, M. (1999) From Regional Development to Local Development: On The Life, Death and Rebirth

(?) of Regional Science as a Policy Relevant Science. - Canadian Journal of Regional Science/Revue canadienne des sciences régionales. 3. (Autumn/automne) 299-314. o.

Raster-Net: The INRETS/DESTs tool for spatial forecastings of european networks, http://www.inrets.fr/ur/dest/europe/pagewebrastergrid.htm.

Sala-i-Martin, X. (2002) The Disturbing ,Rise” of Global Income Inequality, - NBER Working Paper. 8904 o.

Shin, M. E. (2002) Measuring economic globalization: spatial hierarchies and market topologies. Environment and Planning. 34. 417-428. 0 .

Snow, T.-Faye, M.-McArthur, J.-Sachs, J. (2003) Country case studies on the challenges facing landlocked developing countries. - Human Development Report Office Ocassional Paper. Background paper for HDR 2003. UNDP.

Szabó P. (2006) Régió és térszerkezet az Európai Unióban. PhD értekezés, ELTE, Budapest.

Tobler, W.A. (1970) Computer Model Simulating Urban Growth in the Detroit Region. - Economic Geography. 2. 234-240. o.

Varga A. (2002) Térökonometria. - Statisztikai Szemle. 4. 354-370. o.

\section{ELEMENTS OF QUANTITATIVE SPATIAL ANALYSIS IN THE RECENT REGIONAL SCIENCE}

\section{JÓZSEF NEMES NAGY}

Through its half-century of development, though regional science has changed and broadened both in theme and methodology, its primal topic of research is still the relation of space and society, and among its tools of analysis quantitative methods are highly accentuated. A primal issue of quantitative analysis is the study of regional inequalities. Amongst the active factors of spatial fragmentation, representing and measuring the weight and function of space and geographical attributes also require multiple quantitative methods. The analysis of spatial interactions and autocorrelation showing in result of spatial vicinity is the new methodological element prominently in focus of modern regional analyses. 